\title{
9 \\ Theologies of Mana and Sau in Fiji
}

\section{Matt Tomlinson and Sekove Bigitibau}

Nineteenth-century Methodist missionaries saw something miraculous in Fijian mana. David Hazlewood's pioneering dictionary defined mana as a noun meaning 'a sign, or omen; a wonder, or miracle' and an adjective meaning 'effectual; efficient, as a remedy; wonderworking' (Hazlewood 1850: 85). Thomas Williams, who wrote the first major ethnography of Fijian society, explained the name of the god Kanusimana (kanusi means 'spit') by writing that he "'spits miracles," i.e., does them easily' (Williams 1982 [1858]: 218). And when the Bible was translated into Fijian, the noun phrases cakamana and cakacaka mana (working mana) and (vei)ka mana (mana thing/s) were often used for the English word 'miracle $/ \mathrm{s}^{\text {' }}{ }^{1}$

Both missionaries and (potential) converts operated in a world where spiritual power was expected to be made visible and tangible. Yet the missionaries' use of the term 'miracle/s' suggests that mana was seen by them as a kind of going-beyond, a transgression of the normal order of things, when in fact it might well have been woven into that normal order in pre-Christian Fiji. What if there was nothing

1 For early published references to mana in Fiji that do not come from the pens of missionaries, see Charles Wilkes (1845: 209) and Horatio Hale (1846: 399). The former describes the pairing of mana and dina (true) in ceremonial language, which we discuss below; the latter, similar to the missionaries, defines mana as 'a miracle'. 
miraculous about Fijian mana? Indeed, each of the examples given in the opening paragraph raises questions about how missionaries' presuppositions might have shaped their treatment of mana. First, after Hazlewood offered the two definitions quoted above, he added another for mana as an adverb 'used when addressing a heathen deity - so be it, let it be so: also used after uliaing a report expressive of confirmation, as above' (Hazlewood 1850: 85). ${ }^{2}$ This third definition, despite mentioning 'a heathen deity', is less theologically freighted than the first two; it is simply an affirmative and performative speech act, and is no more miraculous than saying 'amen'. Second, Williams' explanation of Kanusimana's name is flawed. In 'Kanusimana', mana is not a grammatical object of spit (kanusi). The name is a verb phrase, and can be translated more accurately as '[his] spit is prophetic' (that is, his spit makes things come to pass), or more compactly as 'magic spit'. ${ }^{3}$ Kanusimana is not spitting miracles, but his spit makes things happen - which, although extraordinary, is quite a different portrayal of magical mechanics than Williams'. Finally, mana in older Fijian accounts is strongly associated with acts of speaking, as we describe below, but the Methodist missionaries who favoured mana-based terms for translating 'miracles' in the Bible used the term vosamana (speak mana) more often to denigrate the lying speech of false prophets than to exalt the effectiveness of divine speech (Tomlinson 2006: 178). ${ }^{4}$

Our purpose in this chapter is not to argue over translations, however. As more than a century of scholarship has shown, isolating the word mana to search for a context-free meaning is not a productive enterprise, and there is an obvious danger in what Michael Lempert (2010: 394) has called 'word prospecting' - pulling terms out of context and treating them as emblems, or fetishising them. There is significant variability in how mana is used in different contexts within a society, between societies, and over time - and the larger point is that terms in language never precisely map onto concepts, practices,

2 By 'uliaing' he means 'to receive a message respectfully; to assent to, or return an answer to a report, or message' (Hazlewood 1850: 157).

3 The translation '[his] spit is prophetic' was suggested in personal communication by Paul Geraghty.

4 Coincidentally, but with suggestive resonance, they also used the term mana for the homonym 'manna' (food from heaven) (see also Kolshus, this volume). Karen Brison writes that Fijian Pentecostals do not often use the term mana, and quotes an interlocutor who says, 'Hmm, man[n]a. That's not really a Fijian word, is it? I think it comes from the Bible and means something like bread' (Brison 2012; cf. Ryle 2001: 233). 
or effects. We focus, rather, on the ways that mana has become an object of analysis by indigenous Fijian Methodist theologians. In the first half of this chapter, we examine mana's association with speech and with the term sau, a word with which mana is often paired and sometimes contrasted. In the second half, we turn to Fijian Methodist theologians' analyses of mana as well as sau, especially as they compare the authority and effectiveness of church leaders with that of hereditary chiefs. Ultimately, we aim to rethink Fijian mana as something which is not necessarily miraculous, but is instead a poetic expression used to articulate and evaluate models of divine and human speech.

\section{Speaking mana}

The first monolingual Fijian dictionary, published a decade ago, defines mana as 'achieving its intended purpose' (yaco dina na kena inaki; Tabana ni Vosa kei na iTovo Vakaviti 2005: 356). This sense of mana, hinted at in Hazlewood's third definition from 1850 ('so be it, let it be so'), is regularly made clear in indigenous Fijian communities during ceremonial speeches. For example, during isevusevu (offerings of kava between guests and hosts), the speeches made by those receiving the presentation feature aspirational phrases such as 'Let fish be abundant' and 'Let chiefly authority be maintained', and those who have given the presentation often respond 'Mana' to these lines; the Methodist theologian Savenaca Vuetanavanua (2009: 35) writes that mana in this context translates as 'May it be so'. ${ }^{5}$ Some events may feature contextspecific wishes, such as a wedding's invocation, 'may the couple live happily together for the rest of their lives'. At the end of the speech of acceptance, all those present often chant together 'Mana, e[i] dina, a muduo'. ' 'Mana, e dina', means 'Mana, it is true'; ' a muduo' does not

5 The Fijian phrases which Vuetanavanua translates as 'Let fish be abundant', and 'Let chiefly authority be maintained' are Cabe tu na ika mai takali and Dei tikoga na itutu vakaturaga. A more literal translation of the first would be '[Let] fish rise from the sea'.

6 Eräsaari (2013: 154) writes that in Naloto village, Verata, mana, e dina is presented as a dialogue, with the individual speech-giver announcing ' $m a n a^{\prime}$ and other participants then responding 'e dina'. In comparison, Bigitibau has observed that a speaker's cadences and voice quality, as well as the specific phrases the speaker uses, can signal to the audience that the speech is about to conclude; if audience members recognise the cues, they are likely to join the speaker in chanting 'mana, e dina', but if they miss the cues, they will chime in with ' $e$ dina' only after 'mana' has been said. On the differences implied by e dina and ei dina in one part of Fiji, see Tomlinson (2009a: 69n5). 
have a literal translation, but is a poetic closure followed by rhythmic clapping and sometimes repetition of 'muduo'. In chanting 'mana, e dina', the thing that is true (dina) is not mana itself. Rather, the thing that is (becoming) true are the words spoken before the chant; for example, the fish will be abundant, chiefly authority will be maintained, and the married couple will live happily ever after.

In such speeches and chants, mana has illocutionary force, per J.L. Austin (1975: 13): 'in saying these words we are doing something'. It also manifests the 'poetic function' of language, per Roman Jakobson, displaying a 'focus on the message for its own sake' (1960: 356). As a formula, 'mana, e dina' follows the previously mentioned metonyms of the good life in traditional Fiji-plentiful food, strong leadership, a happy couple, and so forth - and ties them together with the affirmative and performative chant that aligns mana (may it be so) with dina (what we have said will come to pass). Mana and dina are an irreducible dyad whose utterance ties together and accomplishes what has been said, emphasised by the rhythmic, unified clapping and repetition of muduo which generally follows, with styles varying in different regions of Fiji.

Mana is also linked with speech in the verb phrase vosamana (speak mana). In the 1920s, Methodist minister Epeli Rokowaqa published an account of ancient Fiji in a mission magazine, and of the 20 times his history mentions the term mana, 13 times it is linked with the verb vosa, either in the phrase vosamana, as in 'He was a good man and spoke mana [i.e. he determined the future by speaking]' ('Sa turaga vinaka ka dau vosa mana'), or in more complicated expressions such as 'Those words came to pass' ('A mana na vosa ko ya'; Rokowaqa 1926: 16, 54). In two other cases, Rokowaqa mentions the 'mana, $e$ dina' formula, meaning that in three-quarters of his examples, mana is connected to speech. ${ }^{7}$

7 Rokowaqa's 75,000-word account of Fijian history was published as Ai Tukutuku kei Viti (meaning Stories of Fiji) in 1926. His text contains tales of Fiji's origins, the migrations and wars of the great chiefdoms, and explanations of how the present social order came into being - the chiefly system, orders of hierarchy, and clans' traditional obligations. Rokowaqa had attended the Methodist mission school at Navuloa in the early 1890s (France 1966: 111), and his account of Fijian history has 'a style reminiscent of the Book of Revelation' (Geraghty 1977: 28). 
In looking for early appearances of mana in the Fijian literature, we have found references to it in the Methodist missionary Jesse Carey's survey of his 'native teachers' in Kadavu Island in the mid-1860s. Of the six times that Carey's texts mention mana, it is always used as part of the phrase 'mana, e dina'. In three of these instances, the phrase is attributed to people attending a healing session who are responding to the words of a traditional priest. In two cases, the speaker's identity is not clear. In one case, from the lyrics of a chant (meke), it is a spirit or god who says the words.

Carey's examples from healing ceremonies, which were reported to him by the teacher Joeli Nau, are worth examining for the way they differ on a crucial matter of detail. In the first example, Nau describes a priest praying for a sick person:

\author{
E dua mada na yaqona e laki \\ cabo vua a sa ta[ra]i au tara ga \\ ka bula ga na baca, ni sa oti \\ ko ya ka mama, ka lose ni sa \\ tauya, sa qai masu lakina ka \\ vaka, Ai sevu kei Ravouvou \\ ... kei ira kece ga na Kalou mai \\ na tui cake mai ra tale ga mo \\ dou yalovinaka, ka me bula \\ na mate, era qai vaka, mana \\ e dina, ka sa dina.
}

\begin{abstract}
Kava is presented to him, and when received [he says], 'I receive it, and the sick will get well'; after that [the kava] is chewed and mixed. Upon receiving it, he then prays for it like this: 'The offering for Ravouvou ... and all of the gods from the east and from the west as well. Be merciful and let this sick person be cured'. Then they say, 'mana, it is true', and it is true. (Carey 1865: 198) ${ }^{8}$
\end{abstract}

Thus, this event concludes with the performative utterance of 'mana, $e$ dina' making the healing effective. In comparison, when 'mana, e dina' is mentioned in a discussion of sacrifice (isoro) made for a priest who is sick, there is a coda added:

8 This passage is also quoted in Tomlinson (2006: 175). While conducting research for that article, Tomlinson worked from a transcript of the original document prepared by an anonymous researcher. Since then, he has consulted a microfilmed copy of the original at the Mitchell Library in Sydney and noticed numerous transcription errors which do not, however, change the meaning of the passage. The Fijian versions of the Carey texts presented here are reproduced verbatim except for bracketed inserts and the deleted names of various traditional gods (indicated by ellipses); the idiosyncratic phrasing and (lack of) punctuation in the originals is retained, as well as the inconsistent verb tenses. The English translation of the first example is a refinement of that presented in Tomlinson (2006). 
Nai soro e na vuku ni dua sa tauvi mate, sa vaka oqo. Ke dua na Tabua se liga sa mudu, ka kauta e dua na turaga e na mataqali s[a] yacana nai qaravi, ka laki cabora, ka vaka, Oqo Ratu nai soro e na vukuna na nomu batiniyaqona sa tauvi mate no, ia keitou sa vakawirimadigi, a sa qara vua sa tauvi mate, ia na kenai soro oqo mo lomavinaka me bula, ia, ke vaka ko sa tiko e keri mo vosa mai. Sa qai kaila na bete ka vaka Ai valu! Koi au, a cava talega ko dou tawa kilai au kina? Au sa cakacakava vakal0 ga vei kemudou, ka dou tawa kila ga, e na sega sara ni bula na mate. A sa masu tiko ga na turaga ko ya mo yalovinaka ga me bula, ke vaka e na bula, au na qai tara e dua na nomu Bure vou. Sa qai vakadonuya, io, sa na qai bula; sa qai laki tara na tabua ka vaka au tara ga oqo ka bula ga [na] mate sa qai vaka ko ira kece sa tiko, mana e dina ka sa dina, sa qai masu laka na kamunaga, ka vaka, Au sa qai taura na kamunaga sa kauta mai oqo na qau i qaravi; ka kila ko yau kei Vuetiono...kei ira kece na Kalou vaka [ya]dua ga mai Natuicake, mai ra tale ga meda loma vata me bula na mate. Era qai kaya tale mana e dina, ni sa oti sa qai lako na Bete ka tara na mate me bogi va.
The sacrifice for a sick person is like this. If a whale's tooth or a cut-off hand is taken by a man of a clan, it is called a qaravi, and is formally presented as, 'Ratu, this is the sacrifice for your kava priest who is sick, we have cast lots and it pointed towards the sick, hence this is a sacrifice [on his behalf] that you may grant him mercy and let him live. If you are there, may you speak.' The priest then shouts and says, 'A war! It is I, how come you don't recognise me? I have worked ten times already for you and you still don't recognise me, the sick shall not recover.' But the man continued pleading, 'Be merciful and let him live; if he shall live, I shall build you a new temple.' He then conceded and said, 'Yes, he shall live'; then he went and took hold of the whale's tooth and said, 'I touch this, and the sick shall recover'. All those present said, 'mana, it is true', and it is true, then he prayed over the whale's tooth, 'Now I take this whale's tooth, brought by my servant [or brought as a sacrifice]; and I know, as well as Vuetiono ... and all individual gods from the east and the west as well, let us be of one spirit for the sick to get well.' They all said again, 'mana, it is true', then the priest left to attend to the sick for four nights.

(Carey 1865: 201) 
Whereas in the first example the words are automatically effective, in the second example the priest leaves to attend to the sick person (another priest) for the ritually significant period of four nights, and this physical attention helps to effect the healing. Thus, in the first example, 'mana, e dina' is performative in and of itself: people show their agreement and support by chanting the formula after the words of the priest, and the healing comes to pass. In the second example, by comparison, effectiveness seems to depend partly on the healer making sustained contact with the sick. ${ }^{9}$

Because the utterance of mana concludes ceremonial speeches so prominently, it is easy to imagine how it might be treated as an indigenous emblem, something that defines Fijian spirituality. Indeed, as we discuss below, the Methodist theologian Ilaitia Sevati Tuwere approaches mana in this spirit. Moreover, Sekove Bigitibau has observed how, in his homeland of Nakelo, it is traditional for a person receiving a presentation of kava on others' behalf to say 'kaloumana $i$ dina', linking traditional deities (kalou) to the previously spoken words. (Those on whose behalf the kava is received respond 'mana $i$ dina, sa dina', confirming and supporting what has been said.) Linking pre-Christian spirits, kava and mana, these speech practices are apparently traditional, pre-Christian forms.

\section{Mana? What mana?}

However, several ethnographic reports tell of other Fijians who consider mana to be a foreign term. Buell Quain, who conducted research in Vanualevu in the 1930s, wrote, "The term mana, impersonal supernatural power, is understood at Nakoroka [in Vanualevu] and occurs in ceremonial chants. But the equivalent in the local dialect is sau' (1948: 200n30). In other words, people in Nakoroka knew what mana meant for other indigenous Fijians, and chanted it; but their term for what

9 Over a century after these reports were written, the anthropologist Barbara Herr wrote a doctoral dissertation on psychology and healing in Fulaga which resonates with Nau's second example. Herr wrote, 'The skilled, mature female vuniwai [healers] know medicines in great detail, and they reported receiving intentional instruction. They also, however, believe that the power to heal in their "fingers" is supernaturally dictated. One vuniwai who was also a good friend emphatically stated on several different occasions "sa bau mana a ligaqu!" (lit. my hands really work), to explain the quickness of a cure at her administration' (Herr 1983: 181). She adds 'or "my hands really have mana"' as a possible second translation, but this is misleading, as there is nothing in the Fijian phrase to indicate that mana is a possession. 
Quain knew his audience would consider to be mana was not mana, but sau. (Unfortunately, Quain did not elaborate on what he meant by 'equivalence', nor on the local pragmatics of sau.) A second example comes from a forthcoming book chapter by the French anthropologist Françoise Cayrol based on her research in Vitilevu. She offers the following observation: 'Nasau people insist that the term mana does not belong to the language of the region. Formerly, this term did not exist there; only the idea of sau was present (Cayrol, n.d.).'

Sau can be defined specifically as 'chiefly power' (Eräsaari 2013: 49) or generally as 'powerful and effectively influential to cause ill or good' (Ravuvu 1983: 120). Bigitibau has observed how sau typically refers to individual chiefs and the way their instructions and plans to their people must be followed or else misfortune (accidents, sickness and so forth) will afflict those who have disrespected the chiefs' words.

Theologian Savenaca Vuetanavanua writes, 'On many occasions, sau is used interchangeably with mana (especially in Lau) [eastern Fiji]' (Vuetanavanua 2009: 67; see also Ravuvu 1983: 86). Similarly, anthropologist Steven Hooper, also writing of Lau, states that 'the word sau is often used as an equivalent to mana, although in discussions there was some uncertainty as to whether their meanings were precisely the same' (Hooper 1996: 262). Matt Tomlinson, working in Kadavu, has observed how mana and sau are spoken of together in Methodist discourse, used as a pair in statements meant to glorify God by emphasising God's ultimate power (see Tomlinson 2009b: 76). Bigitibau, who has extensive research experience throughout Fiji, has come to conclude that although indigenous Fijians distinguish between mana and sau in speech, understandings of their differences generally remain unarticulated.

Mana is now prominent in the writings of Fijian authors, and is generally treated in the ways that people from Nakoroka and Nasau seemingly distrust. That is, it is treated as a thing-as spiritual power. As Tomlinson has argued elsewhere (2006), and as suggested above, mana's notional transformation into a thing - the kind of transformation that Roger M. Keesing (1984) accused anthropologists themselves of generating - seems to have been influenced by Methodist missionaries' Bible translations.

In becoming thinglike, mana has also become strongly associated with the power of chiefs. For example, education scholar Unaisi NaboboBaba, in her monograph on indigenous Fijian social science research 
methodology, writes, 'Daily life among the Vugalei [people] includes talk of the mana of chiefs, which is said to be divine' if they have been installed by the people of the land (Nabobo-Baba 2006: 51). Similarly, Asesela Ravuvu wrote that direct or indirect physical contact with a chief was forbidden to lower-ranked people because in making such contact, 'one is not only undermining the veneration and sacredness accorded to the chief, thus weakening his authority and prestige, but one is also being contaminated and affected adversely by his mana' (Ravuvu 1983: 92). Semi Seruvakula, writing in Fijian, cautions that 'it is very dangerous for us to touch the heads and necks of our chiefs, because those are the site of mana and the seat of the sau of the land and people' ('Ia na uludra li se domodra na noda gone turaga sa qai $\mathrm{ka}$ rerevaki sara meda bau tara yani, ka ni oya na itikotiko ni mana ka idabedabe ni sau ni vanua') (Seruvakula 2000: 36). ${ }^{10}$

10 The three most incisive recent anthropological treatments of chiefliness and mana in Fiji have been those of Steven Hooper, John D. Kelly and Matti Eräsaari. Hooper deftly observes the complications of analysing Fijian mana and provides useful summary characterisations, noting mana's connection with chiefs' effective speech, with healing, and with places like the sea (Hooper 1996: 257-59). He also provides useful lengthy transcripts in Fijian of indigenous Fijians' own statements about mana (see also Hooper 1982).

Kelly argues that the mana of Fijian chiefs must be understood as a term dialogically co-constituted with Indo-Fijian shanti ('a conception of religious peace and well-being, the calm after the storm and the experience of grace') (Kelly 2011: 236). The most inspired part of Kelly's argument is his claim that the relative lack of lethal violence in Fiji's coups is due 'almost entirely to the valorization of shanti' by Indo-Fijians, more than three-quarters of whom were Hindus in the mid-1990s and who were the main targets of physical aggression by militant Fijian Christians during the coups of 1987 and 2000 (Kelly 2011: 245). The least convincing part of his argument is his poetic claim that where power (as mana) is truth for indigenous Fijians, truth (as shanti) is power for Indo-Fijians (see also Kelly 2005). The equation of mana with truth, as stated above, is based on the misleading equation of the terms mana and dina due to their use together in ritual speech (see Kelly 2011: 240; see also Hocart 1914; Sahlins 1985; for a critique see Tomlinson 2009a). Kelly's most provocative statement, not yet developed into a full argument, is that 'devotional Hindu values have fundamentally challenged and are altering the practices and significances of ethnic Fijian mana' (Kelly 2011: 246n4); he adds teasingly, 'here lies the truest scandal, if it is true'. This claim, as phrased, is unquestionably true to the extent that indigenous Fijian and Indo-Fijian histories have developed in dialogue with each other since the late nineteenth century: with long-term engagement, there is necessarily challenge and alteration. But an in-depth argument with supporting ethnohistorical and linguistic detail on interactions between those speaking of power in terms of mana and those speaking of truth in terms of shanti, with an eye to reciprocal indigenous uptake of shanti and Indo-Fijian uptake of mana, has not yet been made.

Finally, Eräsaari analyses mana and sau with reference to objects in ceremonial exchange, namely kava and whales' teeth, and notes that when mana is seen as a practice, 'it appears much less "supernatural" or religious than commonly understood. Observed within a sequence where an intention is first declared, then accepted and finally announced, mana becomes the outcome of strictly controlled conditions that ensure the performative quality of these rituals' - with nothing, in short, miraculous about it (Eräsaari 2013: 156). 
It is important to emphasise that mana is not tied exclusively to chiefliness. As seen in the examples above, traditional priests could speak in dialogue with their audiences to act (with) mana. In another example, from a tale told by Rokowaqa, carpenters speak mana when a man named Cameletamana steals an axe from them. The carpenters tell the thief's fellow villagers: 'Whoever stole our axe, he and his descendants will not be able to build boats.' Hence, according to Rokowaqa, 'Those words came to pass [A mana na vosa ko ya], enduring until today, the descendants of Camelematana, who live at Navunivesi, do not know how to build boats' (Rokowaqa 1926: 54). ${ }^{11}$ It is also important to note that much discourse in modern Fiji characterises history in terms of loss, implying that the ability to act with mana is waning for humans, as described at length in Tomlinson (2009b). In the old days, many Fijians indicate, the ancestors were socially unified and acted with strength and propriety under truly authoritative chiefs. Today, in contrast, many people say that chiefs are unable to act in the powerful ways they once did and the social order is breaking down. Figures who can act more effectively are the ancestral spirits who sometimes curse the living. In short, mana in contemporary Fiji is often a diagnostic of what people feel they are losing or have lost.

Methodist theologians do not fully endorse this diagnosis of the decline of mana. Instead, they present mana as something to which they have a special claim as God's representatives. The balance of power between church leaders and hereditary chiefs, all considered to be under God's ultimate authority, is the site of theological argument to which we now turn.

\section{Methodist theologies}

The Methodist Church in Fiji has had a close relationship with many of Fiji's high chiefs for more than a century and a half, but it has had a problematic relationship with the national government in recent years. Fiji became independent from Great Britain in 1970 and has suffered four coups d'état since. In the coups of 1987 and 2000,

11 In the original: 'o koya sa butakoca neimami matau, e na sega sara ni kila na ta waqa, me yacovi ira sara nona kawa ... A mana na vosa ko ya, sa yaco tikoga edaidai, ko ira ga na kawa $i$ Camelematana [sic], era tiko oqo mai Navunivesi era sega sara ni kila na ta waqa.' 
conservatives in the Methodist Church tended to support the actions of coup leaders by justifying them in the name of indigenous rights and against the rights of non-indigenous citizens, primarily IndoFijians, the descendants of indentured immigrants who arrived in Fiji between 1879 and 1916. Progressives and moderates in the Methodist Church were marginalised. In the most recent coup in 2006, however, the Methodist leadership opposed the takeover of governmentit was a coup in which the indigenous-dominated military removed an indigenous-led government - and since then the Church has suffered serious repercussions, including the arrest of leading ministers and repeated cancellation of its annual conference.

In this political context, defining the proper relationship between divine and human power is a matter of urgent concern for many citizens. A theological analysis of the mana or sau of chiefs versus that of church leaders is thus a pressing task, not simply an academic exercise. It is a task that needs to attend to Christianity's profound engagement with the vanua, which means 'land', 'people under a chief', and 'chiefdom', and connotes the system of chiefly leadership, land ownership and ritual exchange which is 'tradition' writ large and publicly displayed. The term vanua is often heard in Fijian religious and political discourse, and it carries strong emotional resonance: the vanua is a homeland, a gift from God, and a group identity, but it is also under threat from modern forces which threaten to dissolve indigenous Fijian unity and compromise land ownership. 'The vanua and the Methodist church are regarded as inseparable by most Methodist church members', as Bigitibau has observed (see Degei 2007: vi), but chiefs, who lead the vanua, also incarnate ancestor gods and therefore might plausibly derive at least some of their efficacy from a non-Christian source (Hooper 1996: 260; see also Nayacakalou 1961: 7; Quain 1948: 200-201).

The foremost thinker on the subject of Fijian mana is theologian Ilaitia Sevati Tuwere, who has served as principal of the Pacific Theological College in Suva (1982-88), president of the Methodist Church in Fiji (1996-98), and an honorary lecturer at the School of Theology at the 
University of Auckland. ${ }^{12}$ In 1992, Tuwere earned his doctorate from the Melbourne College of Divinity with a dissertation on the theology of the Fijian vanua. In 2002, he published a revised version of his dissertation as Vanua: Towards a Fijian Theology of Place; here, we discuss this book rather than the dissertation.

In Vanua, Tuwere devotes an entire section to mana (the book's other three sections are 'Birth', a general introduction; 'Face', on God's emplaced presence; and 'Ear', on the need to listen and to respect silence). In his discussion of mana, Tuwere uses the term to articulate various contradictions in Fijian understandings of spirituality. $\mathrm{He}$ writes that it involves a semantic domain that includes a number of other terms such as tabu, presence, blessing, success, creative force, fertility and more', but also writes that it is integral to sorcery (Tuwere 2002: 142, 161). Mana is implicated in social control, but also in ultimate freedom: Jesus 'is the source of all life-giving mana', and in sacrificing himself on the cross he gave 'lasting mana for all those who believe' and 'for the whole world to have healing and integrative mana'; mana is power, but also powerlessness as seen in Jesus' humility and despair (136, 141, 155, 156, 164, 166-68). Keeping these irreconcilable meanings in tension, Tuwere writes that 'Mana, illustrating the reconciling work of God in Christ ... does not exhaust the nature of God but ... is the only meaningful way of describing God and what his power may mean in the Fijian context' (165).

In his radically inclusive approach to mana, Tuwere, curiously, does not say much about sau. He mentions that the concepts are 'related' and observes sau's resonance with Māori hau (72-73, 147), but does not firmly distinguish the terms. He does, however, cast a politely critical eye on the authority of chiefs, writing:

Chiefs are vital as ritual brokers between spirits and people ... But mana is not simply vested in someone's person or self. It demonstrates itself outwardly through chiefly qualities or $i$ tovo vakaturaga [chiefly customs/behaviour]. I often hear young men in the village saying,

12 We refer to people as theologians if they have earned a Master's or Doctorate in theology. Savenaca Vuetanavanua received his Master's in 2009 from the University of Auckland for a thesis on chiefly installation ceremonies, and three others mentioned in this chapter received their Master's degrees from the Pacific Theological College in Suva: Lesila Raitiqa in 2000 with a thesis titled 'Jesus: Healer of Vanua Sickness and Mana of the Vanua', Apete Toko in 2007 with a thesis on post-coup reconciliation, and Lisa Meo in 1993 with a thesis on garment industry workers. 
Ke ra vinaka walega na noda i liuliu (if only our leaders were good), referring to traditional leaders in general and implying that mana is slipping away from its source. In pre-Christian time[s], lack of mana indicated a defect in the chief's relation with the gods so the rule of the club [i.e., murder] was applied. Today, no action is taken, people merely grumble and speculate. (Tuwere 2002: 138)

In Tuwere's theology, those old gods do have mana (162), but it is a misused mana that is life-destroying rather than life-affirming. To really belong to the land, he argues, Fijians must seek 'new mana in Christ' (158-69): new mana which can overcome the nationalist, pro-chiefly forces that have led Fiji into multiple coups; new mana to straighten out misguided Church leaders who have enabled and even exacerbated the political turmoil in Fiji.

A Methodist theologian whose understanding of mana echoes Tuwere's in some ways, but who emphasises a distinction between mana and sau, is deaconess Lesila Raitiqa. In her Master's thesis, she refers to Jesus as 'the True Mana of the Vanua [land and people]', and writes that 'Mana is something wholesome and good ... [and] belongs to the spirit or the divine realm', even as it is manifest in human qualities (Raitiqa 2000: $53,63)$. These human qualities include markedly aesthetic ones as well as ones associated with raw power. For example, Raitiqa identifies mana with 'the quiet dignity of a chief or royal person' and 'the beauty of kinship' as well as special strength and survival (52-53). Sau, for Raitiqa, is dangerous and frightening, and discovered only when one is afflicted (58). She quotes from an interview she conducted with scholar Pio Manoa in which he stated that 'mana is the fruit of the sau', but Raitiqa characterises the relationship somewhat differently: 'sau is the executor of mana ... A chief would utter an angry word or pronounce a blessing, but it is the sau which [affects] the one for whom the blessing or curse was intended' (58-59). Ethically, for Raitiqa, mana is entirely positive - 'wholesome and good' - but sau, as executive power, is ethically ambiguous.

Another theologian whose understanding of mana resonates with that of Tuwere is Apete Toko, whom Tomlinson interviewed on 10 June 2009 when Toko was the Secretary for the Men's Fellowship of the Methodist Church. Asked about mana and sau, Toko mentioned the performative use of mana in ceremonies - he summarised it as 'Let it be. Me yaco mai [Let it be]. Emeni [Amen]. So be it' - and then moved on to a second meaning: 
E vaka e jiko e dua na, e dua na vakabauta ni tu e so na mana. Na mana ni vanua, na mana ni lotu.... Jiko na mana ni vanua. Na mana rau veiwekani jiko kei na karua ni vosa e vatokai na sau. Na mana ni sau, e dua sa buli me turaga se me tui me liuliu ni, ni dua na vanua. Ah, na mana ni na italatala. Baleta na cava? Baleta ni o koya sa, sa buli, sa lumuji me tamata ni Kalou, talai ni Kalou. Talatala is a person of God. Not only that, but he is anointed. Kevaka sa tu kina e dua na mana levu se sa tu vua e dua na sau, e rawa ni vosa e na yaco na ka e tukuna. Se kevaka e masu me da qarauna na nona masu. Na ka sa na tukuna mai sa na yaco. Ia kena ibalebale na mana vata kei na sau e vaka e sema tu kei na dua na, kei na dua na kaukaua levu e jiko.
It's like there is a, a belief that some mana exists. The mana of the land and people, the mana of the church ... There is the mana of the land and people. Mana is related to a second word, sau. The mana of sau, when one is installed as a chief or paramount chief in order to be the leader of a land. Ah, the mana of the church minister. Why? Because he is, he's installed, he's anointed to be a person of God, messenger of God. The church minister is a person of God. Not only that, but he is anointed. If there is a great mana or he has sau, he can speak and what he said will happen. Or if he prays, we should pay attention to his prayer. What he says, it will happen. This means that it's like mana and sau are joined in a, in a great power that exists.

Like Tuwere and Raitiqa, Toko ties mana to both God and humanity: it is 'of the land and people' as well as 'of the church'. He mentions chiefs in order to explain sau, but then, observing that church ministers are installed or anointed in their positions like chiefs are (or at least as they are supposed to be - many chiefs today are not actually installed; see Eräsaari 2013: 222-23), Toko focuses on the position of the minister, who as a 'person of God' is linked to mana and sau alike 'in a great power that exists'. In short, Toko begins with a Tuwerestyle model of mana rooted in the land and, like Tuwere, goes on to suggest that church ministers are now the ones with the most effective connection to divine mana, which is to say ultimate mana. In this way, Toko's discussion of mana and sau resonates with an earlier discussion 
that Tomlinson had with a Methodist catechist who stated bluntly, 'Mana and sau is with the people of God [i.e., church officials]. Less is with the chiefs of the land of Fiji' (see Tomlinson 2009b: 76). ${ }^{13}$

Lisa Meo, another Fijian Methodist theologian, wrote an entry for the Dictionary of Feminist Theologies in which she describes the Pacific Islands as patriarchal places but does not mention chieftainship specifically. She does, however, explicitly prise open a gap between mana and sau in the same way as Raitiqa. Meo also emphasises the distinction's ethical aspects, drawing a sharper line than Raitiqa does:

For Pacific Island people, theologies are an integration of traditional and Christian beliefs of the nature of God and gods, and a craving for God's power. God's power brings blessings, mana, and to be without God's power means a curse, or sau. One can interpret feminist theologies as an acknowledgment of God's power that will bring forth empowerment for the powerless, especially, in this case, women. (Meo 1996: 109)

For Meo, the key distinction between mana and sau is the ethical evaluation of mana as blessing and therefore inherently good, and sau as cursing and therefore inherently bad. Mana is godly and sau is godless. Her identification of both mana and sau as Pan-Pacific concepts is highly problematic (see also Vamarasi 1987), but her theology is noteworthy for making a clear, explicit break that the

13 This catechist's life had been profoundly influenced by Toko, which is one of the reasons Tomlinson sought out Toko for an interview (see Tomlinson 2009b: 200-202). On mana in relation to chiefs and church leaders, see also Nabobo-Baba's discussion of 'public mana providers' who 'are people who must be present before a function is considered dodonu (correct); they provide mana and blessings to an occasion'; such public mana providers include chiefs and elders, she observes, but also 'increasingly today, a church minister' (Nabobo-Baba 2006: 67-68). 
scholars quoted above do not make: mana is ultimately a thing of the Church and sau is not, meaning the Church has an ethically grounded right to claim power on behalf of the powerless. ${ }^{14}$

\section{Conclusion}

What does this wealth of information actually tell us?

At the very least, it reveals that some indigenous Fijians think mana is foreign and irrelevant, and others think it is the key to the order of the universe and eternal spiritual salvation. Mana cannot be understood without sau, but whether they draw together in similarity as 'a great power' or diverge in opposition as blessings versus curses is not something on which all indigenous Fijians agree. Mana has key aesthetic dimensions, both in its poetic chanting at ceremonies and in theological characterisations of it in terms of dignity and beauty (Raitiqa 2000: 52). It has key ethical dimensions, too, especially when opposed to sau, as in Meo's feminist theology, which explicitly associates sau with the power to curse. These aesthetic and ethical dimensions should both expand and nuance scholarly equations of mana with power and, reading against the grain of early Methodist missionary translations, should trouble any equation of mana and

14 In 2009, Tomlinson also interviewed two Christian ministers who were not theologians but who offered especially thoughtful contributions on the topics of mana and sau. A Seventh-day Adventist minister in Suva, Timoci Beitaki, said that:

mana is God's, it comes from Him, eh? ... Mana belongs to God in heaven because he made things out of nothing. But people in positions of leadership because they are leading, are respected in a chiefly way, and are considered to be sacred chiefs because they are appointed by God, are installed by God, but mana is not with them [the chiefs] ... it is with God, sau is with them [the chiefs] (ki vua na Kalou koya e nona na mana, e? ... Na mana e nona na Kalou ni lomalagi e, baleta o koya e cakava na ka mai, mai na sega ni dua na ka. Ia na tamata na itutu ni veiliutaki baleta ni sa mai veiliutaki sa rokovi vakaturaga ka namaki ni tamata e turaga tabu saka yani era sa mai vua na Kalou, e buli tiko [ira] na Kalou, ia, e sega ni tiko vei ira na mana ... e tiko vua na Kalou, e tiko vei ira na sau). (Interview, 8 June 2009)

A Fijian Methodist superintendent minister (talatala qase), Maika Sorowaqa of the Matuku district in Lau, eastern Fiji, equated sau with cursing like Meo does, explaining, 'here's an example. You say something, it happens. It's like this, if I should curse you. You will go out today, even if you haven't heard what I said, you will meet with misfortune. You'll go and get hurt, eh? ... That's one translation of sau' ('kena vakatautauvata oqo. Mo cavuta e dua na ka, yaco. E va beka qo, me'u cursetaki iko. O na lako nikua, ke o sega ni rogoca noqu vosa, o na sotava e dua na ka rarawa. O lako ga, mavoa, e? ... Ya dua na ivakadewa ni sau'). When asked whether mana and sau were similar or different, Sorowaqa replied that in his opinion they are 'in the same family' (matavuvale vata) (Interview, 2 June 2009). 
truth or mana and miracles. As we have suggested in this chapter, Methodist theologians who attempt to claim the moral authority of the church against the executive authority of chiefs, speaking (with) mana as they do, face the dilemma of valorising tradition and the chiefly system as keystones of indigenous Fijian identity while both depending on and trying to supersede them.

\section{References}

\section{Archival Repository}

Carey, Jesse. 1865. Manuscript in the Methodist Overseas Mission Collection, reel CY509. Mitchell Library, Sydney.

\section{Books, journal articles and chapters}

Austin, J.L. 1975 (2nd ed.). How to Do Things with Words, ed. J.O. Urmson and Marina Sbisà. Cambridge, MA: Harvard University Press.

Brison, Karen. 2012. From mana to anointing: Reformulating Indigenous Fijian agency through global Pentecostalism. Paper presented at the American Anthropological Association meeting, San Francisco, 16 November.

Cayrol, Françoise. n.d. How would we have got here? Unpublished book chapter.

Degei, Sekove Bigitibau. 2007. The challenge to Fijian Methodism - the Vanua, identity, ethnicity and change. M.S.Sc. thesis, University of Waikato, Hamilton.

Eräsaari, Matti. 2013. 'We are the originals': A study of value in Fiji. PhD dissertation, University of Helsinki.

Firth, Raymond, Richard Feinberg, Karen Ann Watson-Gegeo (eds). 1996. Leadership and Change in the Western Pacific: Essays Presented to Sir Raymond Firth on the Occasion of His Ninetieth Birthday. London: The Athlone Press. 
France, Peter. 1966. The Kaunitoni migration: Notes on the genesis of a Fijian tradition. Journal of Pacific History 1: 107-13.

Geraghty, Paul. 1977. How a myth is born - the story of the Kaunitoni story. Mana 2(1): 25-29.

Hale, Horatio. 1846. United States Exploring Expedition during the Years 1838, 1839, 1840, 1841, 1842: Ethnography and Philology, vol. 6. Philadelphia, PA: C. Sherman.

Hazlewood, David. 1850. A Feejeean and English Dictionary. Viwa, Fiji: Wesleyan Mission Press.

Hermann, Elfriede (ed.). 2011. Changing Contexts, Shifting Meanings: Transformations of Cultural Traditions in Oceania. Honolulu: University of Hawai'i Press in association with the Honolulu Academy of Arts.

Herr, Barbara. 1983. Gender and illness among Lauan Fijians: Somatic and affective disorder. PhD dissertation, University of California, Los Angeles.

Hocart, A.M. 1914. Mana. Man 14(46): 97-101.

Hooper, Steven. 1982. A study of valuables in the chiefdom of Lau, Fiji. PhD dissertation, University of Cambridge.

. 1996. Who are the chiefs? Chiefship in Lau, Eastern Fiji. In Leadership and Change in the Western Pacific: Essays Presented to Sir Raymond Firth on the Occasion of His Ninetieth Birthday, ed. Raymond Firth, Richard Feinberg, Karen Ann Watson-Gegeo, pp. 239-71. London: The Athlone Press.

Jakobson, Roman. 1960. Closing statement: Linguistics and poetics. In Style in Language, ed. T.A. Sebeok, pp. 350-77. Cambridge, MA and New York: Technology Press of Massachusetts Institute of Technology and John Wiley \& Sons.

Keesing, Roger M. 1984. Rethinking 'mana'. Journal of Anthropological Research 40(1): 137-56.

Kelly, John D. 2005. Boycotts and coups, Shanti and mana in Fiji. Ethnohistory 52(1): 13-27. 
2011. Shanti and mana: The loss and recovery of culture under postcolonial conditions in Fiji. In Changing Contexts, Shifting Meanings: Transformations of Cultural Traditions in Oceania, ed. Elfriede Hermann, pp. 235-49. Honolulu: University of Hawai'i Press in association with the Honolulu Academy of Arts.

Lempert, Michael. 2010. Review of Gluck and Tsing, Words in Motion. The Australian Journal of Anthropology 21(3): 393-94.

Meo, Lisa. 1996. Feminist theologies, Pacific Island. In Dictionary of Feminist Theologies, ed. Letty M. Russell and J. Shannon Clarkson, pp. 108-10. London: Mowbray.

Nabobo-Baba, Unaisi. 2006. Knowing and Learning: An Indigenous Fijian Approach. Suva: Institute of Pacific Studies, University of the South Pacific.

Nayacakalou, R.R. 1961. Traditional Authority and Religious Sanctions in Fiji. Unpublished seminar paper delivered at the London School of Economics, November 3. Typescript at Pacific Collection, Hamilton Library, University of Hawai'i-Manoa.

Quain, Buell. 1948. Fijian Village. Chicago: University of Chicago Press.

Raitiqa, Lesila Taranatoba. 2000. Jesus: Healer of vanua sickness and mana of the vanua. M.Th. thesis, Pacific Theological College, Suva.

Ravuvu, Asesela D. 1983. Vaka i Taukei: The Fijian Way of Life. Suva: Institute of Pacific Studies, University of the South Pacific.

Rokowaqa, Epeli. 1926. Ai Tukutuku kei Viti. Methodist Missionary Magazine (April): 1-84.

Russell, Letty M. and J. Shannon Clarkson (eds) 1996. Dictionary of Feminist Theologies. London: Mowbray.

Ryle, Jacqueline. 2001. My God, my land: Interwoven paths of Christianity and tradition in Fiji. PhD dissertation, School of Oriental and African Studies, University of London.

Sahlins, Marshall. 1985. Islands of History. Chicago: University of Chicago Press. 
Sebeok, T.A. (ed.). 1960. Style in Language. Cambridge, MA and New York: Technology Press of Massachusetts Institute of Technology and John Wiley \& Sons.

Seruvakula, Semi B. 2000. Bula Vakavanua. Suva: Institute of Pacific Studies, University of the South Pacific.

Tabana ni Vosa kei Na iTovo Vakaviti (Institute of Fijian Language and Culture). 2005. Na iVolavosa Vakaviti (Fijian Dictionary). Suva: Institute of Fijian Language and Culture.

Tomlinson, Matt. 2006. Retheorizing mana: Bible translation and discourse of loss in Fiji. Oceania 76(2): 173-85.

—. 2009a. Efficacy, truth, and silence: Language ideologies in Fijian Christian conversions. Comparative Studies in Society and History 51(1): 64-90.

- 2009b. In God's Image: The Metaculture of Fijian Christianity. Berkeley: University of California Press.

Tuwere, Ilaitia S. 2002. Vanua: Towards a Fijian Theology of Place. Suva and Auckland: Institute of Pacific Studies at the University of the South Pacific and College of St John the Evangelist.

Vamarasi, Jotama. 1987. The mana of the word. In South Pacific Theology: Papers from the Consultation on Pacific Theology, Papua New Guinea, January 1986, pp. 48-51. Parramatta and Oxford: World Vision International South Pacific and Regnum Books.

Vuetanavanua, Savenaca. 2009. Veibuli (Chiefly Installation): A theological exploration. M.Th. thesis, University of Auckland.

Wilkes, Charles. 1845. Narrative of the United States' Exploring Expedition, during the Years 1838, 1839, 1840, 1841, 1842, condensed and abridged. London: Whittaker and Co.

Williams, Thomas. 1982 [1858]. Fiji and the Fijians, vol. 1, ed. G.S. Rowe. Suva: Fiji Museum. 
This text is taken from New Mana: Transformations of a Classic Concept in Pacific Languages and Cultures, edited by Matt Tomlinson and Ty P. Kāwika Tengan, published 2016 by ANU Press, The Australian National University, Canberra, Australia. 